Jurnal of EST, Volume 1, Nomor 1 Juni 2015 hal. 88-98

ISSN:2460-1497

\title{
MODEL PEMBELAJARAN PAI BERBASIS TIK YANG VALID DAN EFEKTIF PADA SMAN 4 KENDARI
}

\author{
Zulkifli Musthan \\ Ahli Pendidkan Agama Islam \\ Institut Agama Islam Negeri (IAIN) Kendari, Indonesia \\ E-mail: zulkiflim58@ymail.com
}

\begin{abstract}
ABSTRAK
Tujuan peneitian ini adalah untuk menghasilkan model pembelajaran PAI berbasis TIK yang valid dan efektif pada SMAN 4 Kendari. Penelitian ini dilakukan dengan menggunakan desain penelitian dan pengembangan dari Borg dan Gall,dan menggunakan pendekatan teknik analisis berbasis ICT. Berdasarkan hasil need asessmen, kajian teori dan hasil penelitian yang relevan disusunlah model awal. Kemudian model awal itu divalidasi oleh ahli. Para ahli menyatakan bahwa model awal itu sudah valid. Kemudian model yang sudah valid itu diuji cobakan secara terbatas (Uji coba I). Hasil uji coba I itu adalah bahwa Model PAI ICT sudah terlaksana dengan baik, tetapi belum efektif, karena ketuntasan klasikal belum tercapai dan aktivitas siswa belum sesuai yang diharapkan. Kemudian merevisi model sebelum dilakukan uji coba II. Hasil uji coba II adalah Model PAI TIK sudah efektif, karena ketuntasan klasikal telah tercapai, aktivitas siswa sudah sesuai yang diharapkan, kemampuan guru mengelola pembelajaran sudah dalam kategori tinggi, respon siswa terhadap pembelajaran dalam kategori positif. Berdasarkan hal tersebut, maka diperoleh model pembelajaran PAI berbasis TIK yang valid dan efektif.
\end{abstract}

Kata Kunci: Model Pembelajaran PAI-TIK, valid dan efektif

\begin{abstract}
This study aimed at producing a valid and effective learning model of ICT based Islamic Education (PAI TIK Model) at a senior high school, SMAN 4 Kendari. The study used Research and Development Design proposed by Borg ad Gall with ICT based analysis approach. Based on needs assessment, theoretical review, and relevant studies, the initial model was developed. Expert validation technique is used to test the validity of the model. The experts stated the model is valid. Model was then tested on a limited basis. The first trial found that the model of PAI TIK was applicable but less effective since both the standard and students' activities have not met the criteria. The model was revised and the second test was conducted. The second trial showed that the model was effective because the students' accomplishment met the criteria and the expected students' activities had been achieved. It was also found that teacher's ability to manage learning and students' response towards learning is in positive category. Therefore, an effective and valid PAI TIK Model is obtained.
\end{abstract}

Key words: ICT based Islamic Education (PAI TIK Model), valid, effective

\section{PENDAHULUAN}

Pendidikan adalah kodrat bagi manusia. Keberadaan pendidikan berlangsung dari satu generasi ke generasi di sepanjang eksistensi kehidupan manusia. Sasaran utama dalam pendidikan adalah membina kemampuan berkreativitas agar segala perubahan yang bermanfaat bagi kelangsungan dan perkembangan kehidupan dapat dicipta. Untuk 
itu, proses pendidikan difokuskan pada pembinaan tiga potensi kejiwaan yaitu rasa, cipta dan karsa yang pembinaannya diarahkan pada pencerdasan spiritual, intelektual dan moral (Suhartono, 2010). Dalam pembukaan UndangUndang Dasar Negara Republik Indonesia tahun 1945 mengamanatkan Pemerintah Negara Indonesia yang melindungi segenap bangsa Indonesia dan seluruh tumpah darah Indonesia dan untuk memajukan kesejahteraan umum, mencerdaskan kehidupan bangsa, dan ikut melaksanakan ketertiban dunia yang berdasarkan kemerdekaan, perdamaian abadi, dan keadilan sosial. Hal tersebut sejalan dengan amanat Undang-Undang RI Nomor 20 tahun 2003 bahwa pendidikan adalah usaha sadar dan terencana untuk mewujudkan suasana belajar dan proses pembelajaran agar peserta didik secara aktif mengembangkan potensi dirinya untuk memiliki kekuatan spiritual keagamaan, pengendalian diri, kepribadian, kecerdasan, akhlak mulia, serta keterampilan yang diperlukan dirinya, masyarakat, bangsa dan Negara. Berdasarkan hal tersebut maka setiap warga Negara apakah secara informal, formal, maupun nonformal wajib ikut serta di dalam kegiatan pendidikan dan seluruh keberadaan manusia dipadati dengan kegiatan belajar. Salah satu bentuk pembelajaran yang diharapkan dapat mengembangkan potensi diri peserta didik dalam proses belajar mengajar adalah dengan menggunakan media berupa peralatan teknologi di bidang informasi dan komunikasi (TIK).

Menurut Yuswohady (2011) pengamat media sosial sampai 30 juta orang Indonesia menggunakannya dan hampir sebagian besar pengguna adalah pelajar. Pelajar merupakan generasi penerus bangsa, dimana pengaruh teknologi komunikasi sangat dominan di kehidupannya oleh karena itu pengarahan positif menggunakan teknologi komunikasi pada pelajar menjadi salah satu tugas bersama baik di dunia pendidikan maupun masyarakat. Tujuan dari sekolah dan kewajiban guru seperti yang disebutkan di atas diperuntukkan pada semua mata pelajaran yang ada di sekolah yang salah satunya di sini yaitu mata pelajaran pendidikan agama Islam (PAI).
Proses pembelajaran di SMA Negeri Kendari disampaikan oleh guru sesuai dengan profesinya atau keahliannya dalam mata pelajaran tertentu dan memanfaatkan teknologi informasi dan komunikasi sesuai dengan topiktopik yang disajikan. Khusus untuk pembelajaran pendidikan agama Islam di SMA Negeri 4 Kota Kendari masih ada guru pendidikan agama Islam yang belum memanfaatkan peralatan teknologi informasi dan komunikasi di sekolah, hal ini disebabkan karena belum terampil menggunakan alat-alat teknologi informasi dan komunikasi tersebut, tetapi sebahagian guru pendidikan agama Islam di SMA Negeri 4 Kota Kendari telah mampu dan terampil menggunakan TIK dalam proses belajar mengajar di kelas (Chairunnisa S.Ag., Guru Pendidikan Agama Islam SMA Negeri 4 Kota Kendari, wawancara tanggal 18 Nopember 2011).

Menurut Drs. Ahmad Daaba, M.Pd (Wakil Kepala Sekolah Bidang Kurikulum SMA Negeri 4 Kendari) menyatakan bahwa pemanfaatan alat teknologi informasi dan komunikasi (TIK) di SMA Negeri 4 Kendari tidak ada model yang baku, tetapi diserahkan kepada guru masing-masing mata pelajaran untuk memanfaatkan peralatan teknologi informasi dan komunikasi dalam pembelajaran. (Wawancara di Kendari pada tanggal 6 Mei 2011). Untuk itu pemberdayaan TIK dipandang perlu karena dinilai dapat meningkatkan pengetahuan dan keterampilan peserta didik dalam proses pembelajaran dan dapat menumbuhkembangkan sikap dan perilakunya pada hal-hal yang positif, dan berusaha menghindar dari hal-hal yang negative. Oleh karena itu jika teknologi informasi dan komunikasi digunakan dalam proses pembelajaran, maka mata pelajaran pendidikan agama Islam di SMA Negeri dapat dikembangkan dan ditingkatkan kualitasnya.

$$
\text { Pendidikan dapat diartikan }
$$

pembimbingan berkelanjutan. Pendidikan merupakan rangkaian proses pemberdayaan potensi dan kompetensi individu untuk menjadi manusia berkualitas. Keberadaan pendidikan melekat erat di dalam diri manusia di sepanjang zaman dan pada diri manusia terkandung hak dan kewajiban kodrat atas pendidikan. Sifat kodrat itu 
disaksikan pada dinamika tiga potensi kejiwaan, yaitu rasa, cipta dan karsa. Untuk itu, maka muncul persoalan tentang pengelolaan daya cipta yang merupakan kebutuhan mutlak yakni pendidikan (Suhartono, 2010).

Dari pemikiran tersebut, jelas bahwa pendidikan adalah masalah khas manusia. Menurut Tirtaraharja (2010) bahwa pendidikan memperhatikan kesatuan aspek jasmani dan rohani, aspek diri (individualitas), dan aspek social, aspek kognitif, afektif, dan psikomotor, serta segi keterhubungan manusia (horizontal), dan dengan Tuhannya (vertical). Oleh sebab itu, seluruh proses pendidikan dan pembelajaran terdorong hanya ke satu arah yaitu pengembangan nilai-nilai kemanusiaan.

Pembelajaran (instruction) adalah suatu usaha untuk membuat peserta didik belajar atau pembelajaran adalah proses, cara, menjadikan orang atau makhluk hidup belajar (Barizi, 2009). Dalam Undang-Undang RI Nomor 20 tahun 2003 tentang Sisdiknas Pasal 1 ayat 20, pembelajaran adalah proses interaksi peserta didik dengan pendidik dan sumber belajar pada suatu lingkungan belajar (Depdiknas, 2003).

Kegiatan belajar hanya bisa berhasil jika peserta didik belajar secara aktif mengalami sendiri proses belajar. Belajar akan efektif jika dilakukan dalam suasana menyenangkan (Dryden, 2002).

Ada 3 (tiga) teori dalam pembelajaran,

yaitu behaviorisme, kognitivisme, dan konstruktivisme. (Mayer, 2001) mengusulkan istilah lain dari ketiga teori pembelajaran tersebut di atas agar mudah dipahami yaitu: a) pembelajaran sebagai penguasaan respons (behaviorisme); b) pembelajaran sebagai penguasaan pengetahuan (kognitivisme); dan c) pembelajaran sebagai konstruksi pengetahuan (konstruktivisme) (Shambaugh, 2006). Seorang guru, harus memiliki sejumlah kiat dalam melakukan pembelajaran, yakni menjadi guru yang dirindukan kehadirannya di kelas (Muchtar, 2010).

Dari uraian di atas, maka dapat dikemukakan bahwa pembelajaran adalah merupakan suatu kumpulan prinsip-prinsip yang terintegrasi dan memberikan preskripsi untuk mengatur situasi agar peserta didik mudah mencapai tujuan pembelajaran, yakni dengan melihat aspek kognitif, afektif dan psikomotorik sesuai yang diharapkan.

Pengembangan adalah proses menerjemahkan spesifikasi desain ke dalam suatu wujud fisik tertentu (Seels, 1994). Proses desain dimulai dari identifikasi masalah atau identifikasi kebutuhan pembelajaran dan diakhiri dengan identifikasi bahan dan strategi pembelajaran, sedangkan proses pengembangan dimulai dari memilih atau mengembangkan bahan pembelajaran dan menuangkannya dalam strategi pembelajaran yang telah didesain, kemudian diakhiri dengan mengevaluasi strategi berikut bahan pembelajaran tersebut, untuk meningkatkan efektivitas dan efisiensinya (Dick, 2005). Berdasarkan hal tersebut, maka pengembangan pembelajaran adalah suatu proses yang meliputi desain, produksi, dan evaluasi.

Model pembelajaran PAI berbasis TIK.Menurut Robbins (1996) mendefinisikan "A model is an abstraction of reality, a simplified representation of some real word phenomenon". Pentingnya model dalam pembelajaran dijelaskan (Gustapson, 2002) bahwa model membantu kita mengkonseptualkan representasi dari kenyataan, menyederhanakan realitas karena kerapkali kondisi nyata terlalu kompleks untuk dipotret.

Penilaian kualitas model pembelajaran merujuk pada kriteria kualitas kurikulum yang dikemukakan oleh Nieveen (1999) yakni (a) validitas dan (b) keefektifan. Untuk menilai validitas model dapat digunakan dua kriteria, yaitu: (1) model yang dikembangkan didasarkan pada rasional teoritik yang kuat dan (2) model memiliki konsistensi secara internal. Sedangkan kriteria keefektifan model ada dua yakni (1) model yang dikembangkan efektif menurut penilaian dan pengalaman ahli atau praktisi dan (2) model yang dikembangkan dapat memberikan hasil sesuai dengan harapan.

Kerangka model pembelajaran PAI berbasis TIK ini terdiri atas syntax, system social, prinsip reaksi, system pendukung, dampak instruksional dan dampak pengiring. 1). Sintaks, merupakan fase-fase atau langkahlangkah kegiatan dalam suatu model yang diwujudkan dalam rangkaian kegiatan 
pembelajaran. 2) Sistem Sosial, merupakan kondisi atau situasi atau aturan yang berlaku dalam suatu model pembelajaran. Pola hubungan antara guru dan siswa menunjukkan pola interaksi dalam pembelajaran dapat berbentuk satu arah, dua arah, atau multi arah. Syah (2000) mengemukakan perlunya komunikasi multi arah dalam situasi pembelajaran dengan harapan untuk menggalakkan student active learning. Hasil interaksi para peserta didik diberi kesempatan untuk melakukan eksperimen dengan objek fisik. Kegiatan belajar seperti ini sesuai dengan perkembangan kognitif peserta didik menurut teori Piaget (1971) sehingga belajar akan lebih bermakna. Sweller (1988) dengan teorinya Cognitive Load Theory (CLT) bahwa pembelajaran terjadi di bawah kondisi yang terbaik yang disejajarkan dengan struktur kognitif manusia.3) Prinsip Reaksi, merupakan pola kegiatan yang menggambarkan respons guru yang wajar terhadap siswa, baik secara individu dan kelompok, maupun secara keseluruhan Joyce (2009) secara garis besar mengemukakan bahwa prinsip reaksi merupakan pedoman bagi guru dalam menghargai dan merespons stimulus berupa perilaku-perilaku siswa dalam proses pembelajaran. 4) Sistem Pendukung suatu model pembelajaran adalah hal-hal yang dapat mendukung tercapainya tujuan pembelajaran dengan menerapkan model itu. 5) Dampak Instruksional dan Dampak Pengiring. Joyce (2009) menegaskan bahwa penerapan suatu model pembelajaran diarahkan untuk menopang pencapaian secara optimal sasaran atau tujuan pembelajaran yang telah ditetapkan. Dampak instruksional untuk model PAI TIK ini adalah tercapainya penguasaan bahan ajar pendidikan Agama Islam khususnya aspek AlQur'an yang berkenaan dengan pencapaian kompetensi dasar dan indicator hasil belajar PAI yang direncanakan dalam RPP. Sedangkan dampak pengiring dalam model PAI TIK ini adalah adanya kemandirian siswa dalam belajar PAI, keaktifan belajar dan sikap positif terhadap mata pelajaran pendidikan agama Islam.
Teknologi komunikasi adalah penggunaan teknologi sebagai media dalam komunikasi manusia. Penggunaan teknologi sebagai media dalam komunikasi ini banyak dipengaruhi oleh perkembangan-perkembangan teknologi dari ilmu pengetahuan lainnya. Rogers (1983) mengemukakan a technology is a design for instrumental action that reduces the uncertainty in the cause-effect relationships involved in achieving a desired outcome. Most technologies have two components: (1) hard ware, consisting of the tool that embodies the technology as material or physical objects, and (2) soft ware, consisting of the knowledge base for the tool. Komunikasi merupakan basic social procces dalam kehidupan manusia. Satu hal yang sangat fundamental dan sangat diperlukan dalam kehidupan setiap manusia. Tanpa kemunikasi manusia tidak dapat berinteraksi dengan orang lain dan tidak akan berkembang. Fenomena inilah yang membuat komunikasi terus mengalami perubahan dan perkembangan yang disebut revolusi teknologi komunikasi. Everett M.Rogers (1983) membagi revolusi komunikasi ini menjadi empat era yakni (1) the writing era of communication, (2) the printing era of communication, (3) telecommunication era, (4) interactive communication.

Pembelajaran Pendidikan Agama Islam di SMA. Pendidikan agama Islam di sekolah dapat dipahami sebagai suatu program pendidikan yang menanamkan nilai-nilai Islam melalui proses pembelajaran, baik di kelas maupun di luar kelas yang dikemas dalam bentuk mata pelajaran dan diberi nama Pendidikan Agama Islam disingkat PAI (Syahidin, 2009). Tujuannya adalah untuk menumbuhkembangkan akidah melalui pemberian, pemupukan, dan pengembangan pengetahuan, penghayatan, pengamalan, pembiasaan, serta pengalaman peserta didik tentang Agama Islam sehingga menjadi manusia muslim yang terus berkembang keimanan dan ketakwaannya kepada Allah SWT;

Perangkat pembelajaran adalah sekumpulan sumber belajar yang memungkinkan guru dan siswa melakukan kegiatan pembelajaran. Ada beberapa komponen 
perangkat pembelajaran dalam penelitian ini, yakni silabus, Rencana Pelaksanaan Pembelajaran (RPP), Materi PAI (pegangan guru dan siswa), LKS, Slide presentation dan alat evaluasi.

Bahan ajar interaktif melalui internet yang digunakan dalam penelitian ini di sajikan dalam program MOODLE melalui website www.http://sman4kendari.sch.id yang telah dirancang untuk membantu guru dalam mengajar. Menurut Munir (2009) Moodle merupakan software belajar dinamis dengan menggunakan model berorientasi objek atau merupakan paket lingkungan pendidikan berbasis web yang dinamis. Menurut Kulik, 1994) bahwa pembelajaran berbasis web diketahui mendukung terciptanya lingkungan belajar yang berbagi pengalaman, interaksi social yang baik dan kolaborasi dalam bekerja. Hasil riset menyatakan bahwa e-learning lebih efektif dalam meningkatkan pemahaman dalam belajar karena adanya visualisasi berupa animasi dan grafik serta bukan hanya teks saja (Scardamalia, 1996). Menurut De Jong (2002) menyatakan bahwa multimedia berbasis web yang didesain untuk pembelajaran dapat meningkatkan pemahaman materi secara keseluruhan.

Berdasarkan uraian pada latar belakang di atas, maka permasalahannya adalah bagaimanakah mengembangkan model pembelajaran Pendidikan Agama Islam (PAI) berbasis TIK yang valid, dan efektif pada SMA Negeri 4 Kota Kendari? Sedangkan tujuan penelitian adalah ditemukannya model pembelajaran Pendidikan Agama Islam (PAI) berbasis TIK yang valid dan efektif pada SMA Negeri 4 Kota Kendari.

Pengembangan Hipotesis.Dengan penggunaan program moodle berbasis teknologi informasi dan komunikasi (TIK) yang valid dan efektif dapat meningkatkan pembelajaran pendidikan agama Islam (PAI) di SMA Negeri 4 Kendari

\section{METODE PENELITIAN}

Jenis penelitian ini adalah Research and Development in Education dan dilakukan di SMAN 4 Kendari kelas XI.IS2 program IPS dan kelas XI.IA1 Program IPA. Sedangkan subjek dalam penelitian ini adalah Guru PAI dan siswa kelas XI.IS2 dan kelas XI.IA1 SMAN 4 Kendari. Adapun objek dari penelitian ini adalah mata pelajaran Pendidikan Agama Islam (PAI) dengan menggunakan fasilitas TIK/Internet program moodle.

Langkah-langkah penelitian mengacu pada tahapan Borg (1981) dapat dikemukakan sebagai berikut: (1) Research and information collecting; (2) Planning; (3) Develop preliminary form of product; (4) Preliminary field testing; (5) Main product revision; (6) Main field testing; (7) Operational product revision; (8) Operational field testing; (9) Final product revision; (10) Dissemination and distribution.

Langkah pertama adalah mengumpulkan data/informasi penelitian yakni mengumpulkan teori pendukung, observasi dalam kelas, dan menyiapkan laporan penelitian studi. Langkah kedua adalah perencanaan yakni mendefinisikan keterampilan, menentukan langkah-langkah kegiatan, dan menguji skala kemungkinan pada tingkatan yang lebih kecil. Langkah ketiga adalah mengembangkan bentuk alat pendahuluan yakni menyiapkan petunjuk materi, buku panduan, dan menentukan evaluasi. Langkah keempat adalah menguji tempat/lapangan awal penelitian yakni produk diujikan pada 1 sekolah, dengan menggunakan 6 sampai 12 subject. Hasil wawancara, observasi, dan data quistionare dikumpulkan dan dianalisis. Langkah kelima adalah merevisi product yakni merevisi produk dengan menggunakan hasil uji lapangan awal penelitian. Langkah keenam adalah menguji tempat/lapangan penelitian inti yakni pengujian ini dilakukan pada 1 sekolah dengan 25-30 subjek. Langkah ketujuh adalah merevisi operasional produk yakni merevisi operasional produk dilakukan melalui hasil uji lapangan inti. Langkah kedelapan adalah uji operasional lapangan yakni dilakukan pada 10-30 sekolah termasuk 40-200 subjek mengumpulkan dan menganalisis hasil intervieu, observasi dan data questionare. Langkah kesembilan adalah revisi akhir produk yakni revisi akhir produk dilakukan berdasarkan hasil uji operasional lapangan. Langkah kesepuluh adalah penyebaran dan 
pendistribusian yakni laporkan hasil penelitian pada pertemuan-pertemuan dan jurnal bekerjasama dengan penerbit yang bisa mendistribusikan hasil secara komersil. Mengawasi pendistribusian agar tetap terkontrol dan berkualitas.

Dalam penelitian ini akan berhenti pada tahap ketujuh, yaitu uji coba lapangan skala terbatas. Untuk tahap kedelapan, kesembilan dan kesepuluh tidak dilaksanakan karena pertimbangan adanya keterbatasan kemampuan pada peneliti.

Desain Uji coba dan Produk Pengembangan. Pelaksanaan uji coba merupakan bagian yang terpenting agar aplikasi yang dihasilkan layak untuk dipergunakan. Tahapantahapannya sebagai berikut: (1) Validasi ahli materi, dan ahli media pembelajaran dan Ahli Teknologi Informasi dan komunikasi (TIK); (2) Analisis konseptual; (3) Revisi pengembangan, berdasarkan penilaian para ahli pada tahap 1 berupa masukan, kritik atau saran ahli materi, ahli media, ahli teknologi informasi dan komunikasi (TIK) selanjutnya dilakukan perbaikan; (4) Uji coba terhadap teman sejawat (guru-guru PAI) dan pebelajar (satu-satu dan kelompok kecil); (5) Analisis konseptual dan produk; (6) Revisi produk (tahap 2); (7) Uji coba lapangan terhadap pebelajar (siswa); (8) Penilaian pebelajar mengenai keefektifan produk.;(9) Analisis empirik (tahap 3); (10) Revisi kecil; dan (11) Terwujudnya produk akhir pengembangan, berupa model konseptual, model prosedural dan model fisikal. Pada tahap ini dihasilkan prototipe 1 (awal) sebagai realisasi hasil rancangan isi perangkat pembelajaran, sehingga dihasilkan pengembangan perangkat pembelajaran Pendidikan Agama Islam (PAI) berbasis TIK/elearning

Kegiatan validasi isi dan validasi konstruk perangkat pembelajaran dilakukan dengan memberikan instrumen validasi pada para pakar dan praktisi. Para ahli yang bertindak sebagai validator adalah pakar pendidikan agama Islam dan yang berpengalaman dalam pengembangan model pembelajaran/ahli Pendidikan Agama Islam, ahli TIK, ahli teknologi pembelajaran dan manajemen pendidikan, serta guru Pendidikan Agama Islam sebagai praktisi. Saran dari pakar dan praktisi tersebut digunakan sebagai landasan penyempurnaan pengembangan perangkat. Kegiatan Ujicoba Lapangan.

Ujicoba dilakukan bertujuan untuk melihat keefektifan perangkat pembelajaran dalam pelaksanaan pembelajaran di kelas. Berdasarkan hasil ujicoba lapangan dan analisis data hasil ujicoba dilakukan revisi. Sebelum ujicoba dilakukan, terlebih dahulu diberikan penjelasan pada guru mitra yang melaksanakan pembelajaran dan pengamat yang mengamati jalannya proses pembelajaran.

Secara umum tentang penyusunan instrumen yang digunakan dalam rangka pengembangan perangkat pembelajaran adalah sebagai berikut : (1) Lembar validitas pengembangan model pembelajaran; (2) Lembar observasi kemampuan guru mengelola pembelajaran; (3) Lembar obsevasi aktivitas siswa; (4) Angket respons siswa; (5) Instrumen penilaian kinerja guru.

Teknik Analisis Data. Adapun kegiatan yang dilakukan dalam proses analisis data kevalidan Model PAI TIK adalah sebagai berikut.

a. Melakukan rekapitulasi terhadap semua pernyataan validator ke dalam tabel yang meliputi : a) aspek $\left(\mathrm{A}_{\mathrm{i}}\right)$, b) kriteria $\left.\left(\mathrm{K}_{\mathrm{i}}\right), \mathrm{c}\right)$ hasil penilaian validator $\left(\mathrm{V}_{\mathrm{ji}}\right)$

b. Menentukan kategori kevalidan setiap kriteria atau aspek atau keseluruhan aspek dengan mencocokan rerata kriteria $\left(\bar{K}_{i}\right)$ atau rerata aspek $\left(\bar{A}_{i}\right)$ ataua rerata total $(\bar{X})$ dengan kategori validitas yang ditetapkan.

c. Kategori validitas setiap kriteria atau setiap atau keseluruhan aspek ditetapkan sebagai berikut:

$$
\begin{aligned}
\quad 3,5 \leq M \leq 4 & \text { sangat valid } \\
2,5 \leq M<3,5 & \text { valid } \\
1,5 \leq M<2,5 & \text { cukup valid } \\
M<1,5 & \text { Tidak valid }
\end{aligned}
$$

Keterangan: 
$M=\bar{K}_{i}$ untuk mencari validitas setiap kriteria,

$M=\bar{A}_{i}$ untuk mencari validitas setiap aspek,

$M=\bar{X}$ untuk mencari validitas keseluruhan aspek.

Kriteria yang digunakan untuk memutuskan bahwa Model PAI TIK memiliki derajat validitas yang memadai adalah (i) nilai $\bar{X}$ untuk keseluruhan aspek minimal berada dalam kategori "cukup valid", dan (ii) nilai $\bar{A}_{i}$ untuk setiap aspek minimal berada dalam kategori "valid". Apabila tidak demikian, maka perlu dilakukan revisi berdasarkan saran para validator atau dengan melihat kembali aspekaspek yang nilainya kurang. Selanjutnya dilakukan validasi ulang lalu dianalisis kembali. Demikian seterusnya sampai memenuhi nilai $\mathrm{V}$ minimal berada di dalam kategori valid.

Analisis terhadap kefektifan Model PAI TIK didukung oleh hasil analisis data dari 4 komponen keefektifan, yaitu (1) hasil belajar siswa, (2) aktivitas siswa, (3) respon siswa terhadap pembelajaran Model PAI TIK, dan (4) pengelolaan pembelajaran dengan Model PAI TIK. Sedangkan keefektifan perangkat pembelajaran diketahui dengan melihat :(1) penguasaan bahan ajar; (2) lembar observasi aktifitas siswa; (3) lembar observasi kemampuan guru mengelola kelas; (4) lembar angket respons siswa. Dikatakan efektif jika memenuhi 3 dan 4 indikator, tetapi indicator 1 harus terpenuhi.

\section{HASIL DAN PEMBAHASAN}

\section{Hasil}

Identifikasi Kebutuhan Awal. Dalam penelitian ini diawali dengan melakukan survey/observasi awal dan melakukan pertemuan dengan guru bidang studi Pendidikan Agama Islam pada SMA Negeri 4 Kota Kendari. Dalam pertemuan tersebut peneliti melakukan wawancara singkat dengan guru PAI untuk mengetahui sejauhmana proses pembelajaran mata pelajaran pendidikan agama Islam dan pendekatan pembelajaran atau model pembelajaran yang digunakan. Dari hasil wawancara tersebut peneliti memperoleh informasi bahwa pelajaran PAI khususnya aspek Al-Qur'an masih sulit dipahami siswa kelas XI-1 (IPA-IPS) dan guru PAI kelas XI-1 belum menerapkan model pembelajaran berbasis TIK khususnya program moodle. Pada kesempatan yang sama peneliti juga membicarakan langkahlangkah metode pembelajaran dengan menggunakan internet program moodle, dan selanjutnya peneliti memberikan informasi tentang jenis penelitian yang akan dilakukan sekaligus merencanakan waktu pelaksanaan penelitian dan kelas yang akan dijadikan sebagai subjek penelitian.

Peneliti juga melakukan survey/need assessment terhadap sekolah, guru dan siswa SMA Negeri 4 Kota Kendari, dengan mengajukan beberapa pertanyaan. Dari keseluruhan jawaban yang dikemukakan dalam angket tersebut, baik yang berasal dari siswa maupun yang berasal dari guru dapat disimpulkan bahwa perlu adanya model pengembangan pembelajaran PAI berbasis TIK pada SMA Negeri 4 Kota Kendari.

\section{Perencanaan Pengembangan.}

Perencanaan yakni mendefinisikan keterampilan, menentukan langkah-langkah kegiatan, dan menguji skala kemungkinan pada tingkatan yang lebih kecil. Keterampilan yang diinginkan dalam penelitian pengembangan ini adalah agar siswa dan guru terampil dalam menggunakan peralatan TIK ke dalam program moodle yang dapat diakses melalui internet, dalam pelaksanaan proses belajar mengajar. Dalam hal penggunaan alat-alat TIK yang dituangkan dalam program moodle, maka disusunlah buku petunjuk penggunaan moodle baik guru, maupun siswa. Selain itu langkah selanjutnya adalah menyiapkan perangkat pembelajaran Pendidikan Agama Islam di Kelas XI sesuai dengan kurikulum yang berlaku. Menetapkan guru mitra dan pengamat, serta tim validator ahli pendidikan.

Desain model dalam penelitian ini adalah pengembangan model pembelajaran PAI berbasis TIK pada SMA Negeri 4 Kota Kendari. Desain model konseptual merupakan desain yang 
berkaitan dengan teori-teori yang melandasai dari proses pengembangan model pembelajaran PAI berbasis TIK, yang melahirkan buku model . Kemudian desain model procedural yakni menggunakan langkah-langkah penelitian dan pengembangan dari Borg \& Gall, sedangkan perangkat pembelajaran PAI menggunakan langkah-langkah dari Dick and Carey. Selanjunya desain model fisikal yakni terwujudnya model PAI berbasis TIK dalam bentuk buku dan compack Disc (CD).

Desain perangkat pembelajaran PAI dapat dikemukakan sebagai berikut: (1) Silabus PAI Kelas XI-1; (2) Materi PAI (Buku Pegangan Guru dan Buku Siswa); (3) Rencana Pelaksanaan Pembelajaran (RPP); (4) Lembar kegiatan siswa (LKS); (5) Slide Presentation dari materi PAI; (6) Petunjuk penggunaan moodle (guru dan siswa); (7) Penilaian/evaluasi hasil belajar.

Sebelum melakukan uji coba lapangan, maka terlebih dahulu dilakukan validasi terhadap produk yang telah dibuat. Validasi dilakukan dengan cara menunjuk ahli di bidang pendidikan. Adapun Uji validasi yang dimaksud adalah sebagai berikut: a) Validasi buku model; b) Validasi Silabus PAI; c) Validasi materi PAI (Buku pegangan guru dan Siswa); d) Rencana Pelaksanaan pembelajaran (RPP); e) Lembar Kerja siswa (LKS); f) Slide Presentation; g) Media TIK; h) Desain pembelajaran; i) Penilaian/evaluasi hasil belajar.

Hasil Validasi Ahli untuk perangkat pembelajaran: Aspek-aspek yang diperhatikan dalam memvalidasi buku model PAI adalah teoriteori pendukung, sintaks, sistem sosial, prinsip reaksi (perilaku guru), sistem pendukung, dampak instruksional dan pengiring, pelaksanaan pembelajaran, lingkungan belajar dan tugas-tugas pengelolaan, dan evaluasi hasil belajar. Adapun rangkuman validasi ahli dikemukakan sebagai berikut: buku model PAI mencapai rata-rata 3,84 yang berarti sangat valid; Validasi silabus mencapai rata-rata 3,82 yang berarti sangat valid, RPP 3,79 sangat valid, Materi PAI untuk guru dan siswa 3,62 sangat valid, slide presentation 3,80 sangat valid, LKS 3,77 sangat valid, petunjuk penggunaan moodle (guru dan siswa)
3,36 valid, evaluasi hasil belajar 3,81 sangat valid.

Analisis keefektifan model dilihat dari aspek aktivitas dan respon siswa serta evaluasi hasil belajar, dan pengelolaan pembelajaran. Hasil keefektifan pada uji coba I kelas XI-IS-2 dan uji coba II kelas XI IA-1 adalah sebagai berikut: Aktivitas siswa mengikuti pembelajaran PAI berbasis TIK dari keseluruhan siswa kelas IPS IS-2 sebanyak 33 orang, terdapat 29 orang atau $87,88 \%$ aktif mengikuti pembelajaran PAI di kelas, sedangkan 4 orang atau 12,12\% kurang aktif karena melakukan kegiatan yang tidak berkaitan langsung dengan pembelajaran PAI. Pada uji coba II siswa kelas IPA IA-1 sebanyak 36 orang, terdapat 31 orang atau $86,11 \%$ aktif mengikuti pembelajaran PAI di kelas, sedangkan 5 orang atau $13,89 \%$ kurang aktif karena melakukan kegiatan yang tidak berkaitan langsung dengan pembelajaran PAI.

Adapun respon siswa kelas XI IS-2 terhadap model pembelajaran berbasis TIK terdapat 85,69 $\%$ menyatakan senang, sangat baik dan positif, dengan alasan bahwa pembelajaran PAI berbasis TIK ini dapat mempercepat proses akses materi, eksploratif, cepat, tepat, efektif, efisien, menarik, menyenangkan dan membangun silatur rahmi melalui diskusi online. Sedang kelas XI IA-1 pada uji coba II dinyatakan bahwa terdapat 90,75 $\%$ menyatakan senang, sangat senang dan positif terhadap model pembelajaran PAI berbasis TIK.

Sedangkan pengelolaan pembelajaran oleh guru PAI dinilai terlaksana seluruhnya yang mencapai rata-rata 3,04 untuk kelas XI IS-2 dan 3,21 untuk kelas XI IA-1.

Hasil belajar pre test siswa kelas XI-IS-2 yang berjumlah 33 orang (muslim-muslimah) sebelum uji coba I dimulai menunjukkan bahwa yang mendapatkan kategori sangat rendah sebanyak $87,88 \%$ yang berarti bahwa lebih dari $50 \%$ siswa tidak mencapai standar ketuntasan belajar yang diharapkan. Sedangkan hasil belajar post test atau setelah dilakukan 6 kali pertemuan, maka hasilnya adalah terdapat 45,45 \% mendapatkan nilai sangat rendah, rendah sampai tinggi mencapai 54,55 \% yang berarti bahwa lebih $50 \%$ siswa telah mencapai standar ketuntasan belajar yang diharapkan. 
Nilai hasil belajar uji coba II pada kelas XI-IA-1 adalah sebagai berikut:Hasil belajar pre test siswa kelas XI-IA-1 yang berjumlah 36 orang (muslim-muslimah) sebelum uji coba I dimulai menunjukkan bahwa yang mendapatkan kategori sangat rendah sebanyak 19 orang atau $52,78 \%$, 14 orang atau 38,89\% mendapatkan nilai rendah, sebanyak 3 orang atau 8,33\% mendapatkan nilai sedang. Tidak satupun yang mendapat nilai tinggi dan sangat tinggi. Jadi lebih dari $50 \%$ siswa tidak mencapai standar kompetensi belajar yang diharapkan.. Sedangkan hasil belajar post test atau setelah dilakukan 6 kali pertemuan, maka hasilnya adalah terdapat 1 orang atau 2,78\% mendapatkan nilai sangat rendah, kemudian 1 orang atau $2,78 \%$ yang mendapat nilai rendah, terdapat 22 orang atau $61,11 \%$ yang mendapat nilai sedang, dan yang mendapat nilai tinggi sebanyak 12 orang atau 33,33\%, dan tidak ada satupun siswa yang mendapatkan nilai sangat tinggi. Jadi terdapat $73,44 \%$ berada pada kategori sedang dan tinggi, yang berarti bahwa lebih $50 \%$ siswa telah mengalami peningkatan hasil belajar yang diharapkan dengan kata lain telah mencapai standar ketuntasan belajar yang diharapkan.

\section{Pembahasan}

Ketercapaian Tujuan Penelitian. Berdasarkan hasil uji kevalidan yang telah dikemukakan pada pembahasan sebelumnya dapat disimpulkan bahwa Prototipe-1 (Model PAI TIK, Perangkat, dan Instrumen yang bersesuaian) seluruhnya telah memenuhi kriteria kevalidan, walaupun tidak secara serentak dicapai.

Hasil penilaian ahli dan praktisi ternyata model PAI TIK dinyatakan valid ditinjau dari keseluruhan aspek/komponen model, namun demikian teori-teori belajar yang dikemukakan dianggap belum cukup untuk mendukung model PAI TIK. Beberapa penilai menyarankan bahwa model PAI TIK harus tetap didasari oleh teori konstruktivisme, agar tidak terkesan bahwa model ini hanya berpusat pada guru (teacher oriented). Setelah dilakukan revisi seperlunya, maka model PAI TIK ini dapat diterapkan pada pembelajaran Pendidikan Agama Islam yang berpusat pada guru dan siswa. Demikian juga perangkat pembelajaran (Silabus, RPP, Materi/buku modul siswa dan guru, slide presentation, LKS) yang semula didominasi dengan penyajian secara langsung, maka setelah direvisi penyajiannya menjadi penggabungan yang berimbang antara penyajian langsung dengan pengkonstruksian oleh siswa dengan media internet program moodle terhadap materi pembelajaran PAI.

Keefektifan pembelajaran Model PAI TIK ditentukan oleh 4 hal, yaitu ketuntasan klasikal, aktivitas siswa, kemampuan guru mengelola pembelajaran, dan respons siswa terhadap Model PAI TIK. Pada uji coba I respon siswa Kls XI-IS-2 (IPS) SMA Negeri 4 Kota Kendari yang berjumlah 33 orang, pada materi PAI mencapai $97 \%$ menyatakan senang dengan materi PAI, Slide presentation mencapai $87,9 \%$ menyatakan senang dengan adanya slide presentation, Lembar Kegiatan Siswa (LKS) mencapai $81,8 \%$ menyatakan senang dengan adanya LKS, tugas mencapai $87,9 \%$ menyatakan senang dengan adanya pemberian tugas, kuis mencapai 81,8 \% menyatakan senang dengan adanya kuis, dan uji kompetensi mencapai 78,8 $\%$ menyatakan senang dengan adanya uji kompetensi.

Pada uji coba II respon siswa Kls XI-IA1 (IPA) SMA Negeri 4 Kota Kendari yang berjumlah 36 orang, pada materi PAI mencapai 91,7 \% menyatakan senang dengan materi PAI, Slide presentation mencapai $94,4 \%$ menyatakan senang dengan adanya slide presentation, Lembar kegiatan siswa (LKS) mencapai 83,3 \% menyatakan senang dengan adanya LKS, tugas mencapai 91,7 \% menyatakan senang dengan adanya pemberian tugas, kuis mencapai 91,7 \% menyatakan senang dengan adanya kuis, dan uji kompetensi mencapai 91,7 \% menyatakan senang dengan adanya uji kompetensi.

Hasil-hasil yang diperoleh terkait dengan keefektifan Model PAI TIK tersebut menunjukkan adanya kesesuaian dengan hasilhasil yang terkait kepraktisan Model PAI TIK. Pada Uji coba I dan II seluruh komponen keefektifan telah memenuhi kriteria, yaitu respons siswa terhadap pembelajaran Model PAI 
TIK.Hal tersebut disebabkan karena pembelajaran Model PAI TIK baru pertama kali diterapkan.

Pada Uji coba I respons siswa terhadap pembelajaran Model PAI TIK sudah positif, namun kemampuan guru mengelola pembelajaran masih belum memenuhi kriteria, demikian juga aktivitas siswa baru dua dari empat jenis aktivitas yang memenuhi kriteria, dan hasil belajar (ketuntasan klasikal) baru mencapai 45,6\%. Keadaan seperti ini memberikan indikasi bahwa pembelajaran Model PAI TIK yang bercirikan keterlibatan nuansa penggunaan moodle dengan internet sudah dapat menjadikan para siswa tertarik, namun belum ditunjang oleh kemampuan guru yang diharapkan, demikian juga aktivitas dan hasil belajar yang ditunjukkan siswa belum sesuai yang diharapkan.

Pada Uji coba II guru tampil lebih baik setelah diberikan arahan-arahan, namun demikian kemampuan guru yang sudah memenuhi kriteria, namun belum dapat memberi dampak maksimal terhadap ketercapaian kriteria dua komponen lainnya, yaitu ketuntasan klasikal dan aktivitas siswa, tetapi semua komponen mengalami peningkatan, baik yang telah memenuhi kriteria pada Uji coba I maupun yang belum. Pada Uji coba I ketuntasan belajar hanya 45,6 \%.menjadi $72,1 \%$. Respons positif siswa terhadap pembelajaran adalah $85,9 \%$ pada Uji coba I menjadi $90,75 \%$ pada Uji coba II.

\section{SIMPULAN DAN SARAN}

Simpulan yang dapat ditarik dari penelitian ini adalah telah diperoleh model pembelajaran PAI berbasis TIK pada SMA Negeri 4 Kota Kendari yang memenuhi kriteria valid, dan efektif. Model PAI TIK tersebut memiliki sintaks pengajaran langsung dengan fase-fasenya, dan memiliki komponen lain yang meliputi teori pendukung, interaksi social/system social, prinsip reaksi, dan system pendukung perangkat pembelajaran yang semuanya valid.

Berdasarkan hasil dan temuan yang diperoleh dalam penelitian ini, dikemukakan beberapa saran atau rekomendasi sebagai berikut: (1) Penelitian ini sudah menghasilkan Model
Pembelajaran PAI berbasis TIK yang valid, ,dan efektif. Oleh karena itu disarankan kepada guru PAI untuk mengimplementasikan model ini pada ruang lingkup yang lebih luas, baik dari segi materi maupun dari segi jenis dan jenjang pendidikan;(2) Model PAI berbasis TIK ini tidak hanya dapat digunakan dalam pembelajaran pendidikan agama Islam, tetapi dapat juga digunakan pada pembelajaran agama pada umumnya, dan mata pelajaran lainnya; (3) Untuk keperluan diseminasi produk dapat diujicobakan terhadap sekolah-sekolah yang memiliki fasilitas infrastruktur berbasis TIK yang memadai dan kepada guru serta siswa baik yang telah maupun belum memiliki keterampilan dasar TIK.

\section{DAFTAR RUJUKAN}

Barizi,A. \& Idris.M. 2009. Menjadi Guru Unggul Bagaimana Menciptakan Pembelajaran

yang Produktif dan Profesional. Yogyakarta: ArRuzz Media.

Borg, Walter R.1981. Applying Educational Research A Practical Guide for Teachers. New York \& London: Longman Inc.

De Jong, T and Van der Hulst,A. (2002), The Effectiveness of Computer Based Learning.

Journal of Computer Assisted Learning I (18):219-231

Depdiknas. 2003. Undang-Undang Republik Indonesia Nomor 20 Tahun 2003 tentang Sistem Pendidikan Nasional. Jakarta: Biro Hukum dan Organisasi Depdiknas.

Dick, Walter., Carey, Lou. \& Carey, James O. 2005. The Systematic Design Of Instruction $\left(6^{\text {th }}\right.$ ed.). Boston, Pearson

Dryden,Gordon \& Vos, Jeannette. 2002. Revolusi Cara Belajar The Learning Revolution. Bandung: Kaifa

Gustapson, Kent L. \& Branch, Robert Maribe. 2002. Survei of Instructional Development Models. New York, Eric Clearinghouse on Information \& Technology Syracuse University. 
Joyce, Bruce, dkk.2009. Models of Teaching. New Jersey: Pearson Education, Inc.

Kulik C \& Kulik J. 1994. In: Baker EL \& O’Neill HF (eds) Technology assessment in Education and Training. New Jersey, Hillsdale: Lea Publishers

Mayer E.Richart. 2001. Multimedia Learning. New York: Cambridge University Press.

Mukhtar \& Iskandar. 2010, Desain Pembelajaran Berbasis Teknologi Informasi dan Komunikasi (Sebuah Orientasi Baru). Jakarta: Gaung Persada Press

Munir. 2009. Pembelajaran Jarak Jauh Berbasis TIK. Bandung : Alfabeta.

Nieveen, Nienke.1999. Prototyping to Reach Product Quality. In Jan Van den Akker,

R.M. Branch, K. Gustafson, N. Nieveen, \& Tj. Plomp. Design Approaches and Tools in Education and Training. Dordrecht, The Netherlands: Kluwer Academic Publisher.

Piaget,J. \& Inhelder,B. 1971., Mental Imagery and the Child. New York: Basic Books

Robbins, Stephen P. 1996. Organizational Behavior: Concepts, Controversies, Applications ( $7 \mathrm{~m}$ Ed.). Prentice-Hall International, Inc.

Rogers, Everett M.1983. Diffusion of Innovations. New York: Frce Press

Seels, Barbara B. \& Rickey, Rita C. (1994), Instructional Technology: The Definition and

Domain of the Field. Washington DC, Association for Educational Communication and Technology.

Suhartono, Suparlan. 2010. Pengantar Ilmu Pendidikan. Makassar: Badan Penerbit UNM

Scardamalia, M., and Bereiter, C., Schofield,J.W. 1996. Computers and Classroom Culture. New York: Cambridge University Press.

Shambaugh, Neal \& Susan G.Magliaro. 2006. Instructional Design. United States of America:Lybrary of Congress Cataloging in Publication Data.
Syah, Muhibbin. 2000. Psikologi Pendidikan Dengan Pendekatan Baru. Bandung: PT.Remaja Rosdakarya.

Syahidin. 2009. Menelusuri Metode Pendidikan Dalam Al-Qur'an. Bandung: Alfabeta

Tirtaraharja, Umar. 2010. Pengantar Pendidikan. Makassar: Badan Penerbit UNM.

Yuswohady.2011. h.1 (http://networked blog.com/cygRx). 